\title{
Political System Discussions in Turkish Media
}

\author{
Assoc. Prof. Dr. Vildan lyigüngör
}

Marmara University Istanbul Turkey

\section{Doi:10.5901/mjss.2013.v4n10p204}

\begin{abstract}
In Turkey, after 2002 general elections the "Justice and Development Party" has come to the government by itself. Demilitarization of the political system of Turkey was gradually compleded and a new, civilian, participatory constitution is required. Discussions on a required new constutition has been accompanied by the strengthening the executive branch. In crisis situations, instead of strengthening the democratic partipatory institutions, it is always preferable to reorganize the political institutions in favor of the executive branch. In this context presitential system or semi-presidential system have been seen as a new model of govenment and guaranty of the stability of govenment instead of the existing semi-parliamentary / or / semi-semi-presidential political system. The media as an ideological aparatus of the state has been acted its role on the discussion programmes. The academicians, intellectuals and journalists as organic intellectuals have been discussing on "which political system is good for our democracy?" In this paper, it is aimed to analize the TV discussion programmes on a new political system. Metedologically three TV news channels and their discussion programmes will be chosen throughout four weeks. It is intended to analize the program contents on democratic discurses.
\end{abstract}

\section{Introduction}

In Turkey, in the 1980's, the national development policies and the import substitution policies came to an end and the national economy has been articulating the global economic system by using "stabilization programmes" and "structural adjustment programmes".

The 1990s was a long decade of political instability which determined the political agenda with coalition governments and constant indirect interventions by the Turkish army that have been called Praetorianism. After the 2002 general elections, the "Justice and Development Party" won a majority in parliement. During its time in power, AKP (Justice and Development Party) has succeeded in reducing the functions of the army with in the political system, changing many Articles of the Constitution and some laws. Decreasing the direct or indirect interventions of the armed forces primarily at a legal level (by changing the laws), AKP intended to change the 1982 Constitution, made by the military regime. An expectation of a more liberal, participatory, pluralistic constitution relying on a consensus of different social groups has appeared in Turkish society. Besides democratic expectations, discussions of political system specificially the "presidential system" have entered the political arena.

Methodologically, an instutional approach has been used with Poulantzas's "authoritarian statism" conceptualization. Three news channels and their three TV discussion programmes were chosen for study over a four month period. Media, as the ideologically most important and impressive aparatus of the state, made programmes to gain the consent of a large part of society. It is intended to analyse the discourses of the debates in the discussion programmes.

\section{2. "Authoritarian Statism"}

Poulantzas's conceptualization "authoritarian statism" helps us to understand the discussion of political system at the same time as the instutional approach. In his book State, Power, Socialism he stated that a new form of state appeared.( was going to appear). This means, the institutions of political democracy and formal liberities will be gradually weakened and state control will be intensified throughout social and economic life. Authoritarian Statism, represents the new "democratic" form of bourgeois republic in the actual phase (Poulantzas, 2004: 234).

Following Poulantzas, Bob Jessop defined the characteristics of Authoriterian Statism as, the political power delegated to the executive branch from the legislative branch and the personalization of power intensifies in the prime minister or (here) president. Legislative, executive and juridical powers tend to become integrated. The State of Law 
weakens in favour of Personalization. Giving up their traditional roles, political parties take on transmission roles for the executive branch. Media becomes an ideological aparatus of the state creating the political legitimacy and the power of control of the media gradually expands. At the same time as some forms of neoliberal legitimacy, a plebiscitary and populist technology of consent spreads out (Jessop, 2005: 100-101).

\section{Neoliberal Economic Policies and the Crisis or A Brief History of Presidential System Discussions}

The history of political system discussions goes back to the 1980's when Turgut Özal's "Motherland Party" (ANAP) was in power during his prime ministery and presidential term. In economic crisis situations it is always preferable to change political institutions in favour of the executive branch. The center right had come together under the flag of ANAP and Özal's desire for a very powerful executive determined the discussions on political system at that time. But ANAP had appeared to be a Leader Party, it's life depended on it's leader's life. After Turgut Özal's unexpected sudden death the political system discussions were suspended.

Articulating with the world system by way of structural adjustment and stabilization programmes, the Turkish economy entered in neoliberal process after the 24 January 1980 economic decisions. According to the 1961 Constitution Turkey's governmental system was very typically parliamentary, the executive branch was double - headed, president and prime minister and his / her government. Presidental elections were indirect in that parliement elects the president as the non-responsible head of the executive branch. In 1971 some of the Articles of the Constitution had been changed by the intervention of the armed forces in favour of the executive branch of the parliamentary system.

In the second half of the 1970's, a structural crisis of capitalism effected the Turkish economic system, especially in 1977. The import substitution development model had come to it's end. In the sense of a Gramscian hegemonic crisis, this economic crisis had turned into political crisis, the political institutions collapsed, the social opposition movements arose all over the country. The military coup d'état and its General had presented itself as a moderator above all of the classes, all of the social groups and thus took political power. At the same time as following the neoliberal economic policies, the constitution and almost all the political institutions had been changed radically by the violence of the state. The parliamentary system - seen to be responsible for the political crisis - had been changed in favour of the executive branch, and the president's political authority was expecially enhanced. But political practice remained parliamentary. During the ANAP period, after Turgut Özal's prime ministry, he was indirectly elected as president, by parliament. Following Duverger, the "system's political practice appeared as presidentialism" (Stepan\&Skach, 1994: 134-135) at that time. The political system operated, the party in power had a majority in parliament and the president was from the same party.

Every crisis is indeed a resettlement process; economic reorganisation processes need political and administrational regulation. The "president" (Özal, calling himself that, recalled the United States president in people's minds) twisted the system with the help of the majority of his party in parliament. As the politically non-responsible head of the executive branch, issuing Decree Laws, took the authority from the legislative to the presidency. Because of the falling profit rates of capital that had caused the economic crisis, the state was reorganized by delegation of authority from the legislative to a strong executive and the decision-making processes were separated.

After the AKP's $57.88 \%$ success in the 12 September 2010 referendum, some changes accepted in the existing 1982 Constitution made by the military regime on 12 September 1980, expectetions of a more participatory, liberal, inclusive of human rights and social consensus constitution have risen in responds to the demands of individuals and many social groups. Discussions on the new constitution have taken place on platforms such as congresses, conferences, forums and especially in the media, by academicians, journalists, politicians and members of many pressure groups. The government party's leader, Erdoğan, decleared a new constitution had to bring a new government system, a presidential system. The new constitution discussions have turned into new political system discussions and engaged the political agenda, dating from the referendum results.

Indeed, Turkey's political tradition has always been parliamentary; the proportional representation election system fosters a multiparty system that represents the different groups in society. One of the most remarkable tradition is the political parties' strongly diciplined attitude in the legislature. The "necessary condition" of the parliamentary system is party dicipline, without party dicipline the system turns into inoperative legislative government (Sartori, 1997:127).

\section{AKP Party and Reorganization of the Political and Administrative Spheres}

After the AKP came to power in 2002, the party's leader, Recep Tayyip Erdoğan, has expressed a desire for political 
system change. In most of his speeches begining from 2003, he decleared a presidential model like in the United States. The AKP is a massive, dominant governmental party. In the 2011 general election it took $49.83 \%$ of the votes and has won 327 seats in parliament, gradually increasing its votes since 2002 to the last 2011 general election.

When we look at the history of political system discussions, it is easily seen that party and its leaders who believe in and so enthusiastically pursue neoliberal economic policies want to change the system to presidentialism. At the institutional level a strong and stable executive to accelerat decision-making processes is required. Presidentialism comprises some difficulties, it operates in the form of winner-take-all; this makes democratic politics a zero-sum game (Linz, 1992: 123). So the functions of opposition party or parties decrease in the political sphere. During its years in power AKP has provided continous absolute majority in parliament and has been the dominant party for 11 years. At institutional level it hasn't confronted any problems that could create political instability. Relying on its majority in parliament in the legislation processes for constitutional changes and as a part of global economic policy made in accordance with these decisions changed the public administration and more importantly changed the juridical system profoundly.

One party with absolute majority in parliament and with a personalization of power operates like presidentialism. Only the leader -the prime minister- speaks (only a few of the other ministers in the government speak only on their own areas) and has a strong control over the government and over his party; that leads to the personalization of power. It looks very similar to a presidential system when the prime minister has the majority of parliament fbehind him as in the case of AKP party.

According to the draft AKP constitution, the president has the authority to issue executive decrees. The legislative delegates its authority to the executive, to the president. Thus the president can decide to send the army abroad although this power belongs only to the legislative in every other constitution.

The most remarkable article of the draft AKP constitution, is the power of the president to dissolve parliament. This is different from United States and also different from Latin American countries presidential systems. The president and the members of parliament will be elected at the same time by the electorate. Division of power as the defining feature of presidentialism is refused. Here, a strong leader is wanted for the future of AKP governments, but full presidential system as in the United States, is not considered. If the president and the parliamenter majority are from different political parties, the president can dissolve parliament himself (or herself). So elections will be a kind of plebiscit, and this will be reinforced by the personalization of the president. Whenever the president wants, the cicumstances to favour him (her), parliamentary elections will be repeated in practice.

Karl Marx in his book "18th Brumaire of Louis Bonaparte" emphasized dual democratic legitimacy: "The elected National stands in a metaphysical relation, but the elected President in a personal relation. The Natioal Assembly, indeed, exhibits in its individual representatives the manifold aspects of the national spirit, but in the President this national spirit finds its incarnation. As against the Assemly, he possesses a sort of divine right; he is President by the grace of the people" (1976: 33; and Linz, 1994: 8). Here, Marx predicted that the sharing of authority between the president and the National Assembly would be ended by the 1848 Constitution in France. The Achilles heel of the institutional and constitutional structure collapsed 'at touch of the thricorn hat of Napoleon'.

There is no democratic principle in presidential regimes based on dual democratic legitimacy that can decide who represents the will of the people in principle (Linz, 1994: 7).

\section{TV Discussion Programs on Political System: Manifacturing Consent}

Three TV news channels, "CNN Türk", "NTV" and "Habertürk" and their live discussion programmes "Ne Oluyor?", "Dört Bir Taraf", "Türkiye'nin Nabzl" have been chosen. It is aimed to analysis the debaters' discourse in the context of democracy.

The CNN Türk channel, "Ne Oluyor?" ("What is Happening?") discussion programme, has a presenter and mostly calls academicians, technocrats, ministers. The debaters are invited to discuss "political systems and constitutions", the chief of "constitution comission" and at the same time member of parliament, on the one side, on the other side the professors of constitutional law or political science from the universities. Mostly the presenter intervenes the discussions for explanation for audience when discussions go to technical extend.

On the NTV programme, "Dört Bir Taraf" ("Four Sides") there is no presenter. Four journalists -two women and two men- discuss the actual issues among themselves, and each of them is moderator in turn. Two of the journalists are close to the government, the others stand in critical opposition. 
On the Habertürk channel, "Türkiye'nin Nabzı" ("Turkey's Pulse") discussion programme, there is a presenter, The program host academicians, technocrats, journalists and political party members. The programme has a phone connection to the hosts from other cities outside of Istanbul.

The debaters talk about; division of power, the president's authority over the legistlative branch and juridical independence, on the necessity of political system change. Relations between different political systems and economic develoment and strong democracy.

1) All of the debaters agree that the Turkish model of presidential system has unique characteristics, dissimilar to the other country's models such as the United States and Latin American Countries. This is called the "Turkish presidential system" ("a la turca system").

2) The members of govenment (members of parliament or ministers) and the journalists close to the government, emphasize the "stability of government", the "economic development", the "continuity of administrative and economic reforms"; the debaters who criticize the presidential system for Turkey, the parliamentary system has to continue for sake of democracy's stabilization.

3) The presidential system provides political stability as against coalition governments comprised of many parties. The other debators insist that elections and the political party system provide the political stability, it doesn't need to change the governmental system. But it needs to change the law on political parties and improve their internal democracy as against the party leaders' hegemony.

4) The divion of powers, checks and balances, have disappeared in favour of a president, a very powerful president required to provide political stability is demanded by the debaters on the government side. The opposition debaters insist on with this kind of president the regime will turn on an authoriterian way in contrast to the claims about president's authority will decrease.

5) One side of the debate, connects the presidential system to the "rate of economic development", the orhers stress the importance of subjects like "human development index", "women's condition and development" "political development" or "strong democracy".

6) The debators on the government side insist on reducing the party system to a two party system. The others are various other agendas.

\section{Conclusion}

AKP party has been in political power since 2002. In this very powerful period the party leader and his staffs have suggested that the political system should change from parliamentarianism to presidentialism. In Turkey, all of the political parties generally agree on neoliberal economic policies. The neoliberal hegemony has lasted. With a strong executive, the actual and probable crisises have been overcome. Presidential government leads to the personalization of power. The President's strong claim to democratic, even plebiscitarian, legitimacy is a danger to democracy when he (she) manipulates public emotions to strengthen his (her) power or popularity. Legislative, executive and juridical powers will become integrated. As a result of the personalization the state, the state of law weakens.

Turkey's tradition is a parliamentary system. Even using the techniques of social engineering the political parties well diciplined structure can not be changed, this is also a deeply rooted tradition.

The question is "why does the AKP party, especially its leader, have such a strong desire for a "Turkish kind of presidentialism" The answer has to be not only (full) economic, but at the same time cultural. They want to perform a kind of social engineering to make changes, reforms to social life in such areas as education, the family and the women and envorimental policies.

Television programmes about political systems, are part of the ideological aparatus of the state for manifacturing consent. Mostly the discussions turn around the complicated and technical subjects especially on law that the ordinary audience could find difficult to understand. Some of the debaters speeches manipulate national feelings about the President's personalization essence using the ideas of "powerful executive" with "powerful president" and in its turn "powerful state". Democracy doesn't need the touch of any kind or any colour of hat instead of participatory and promoting freedom.

Instead of asking which political system provides the most the stable government, it is beter to ask which political system provides more participatory democracy. 


\section{References}

Blondel, Jean (1984) 'Dual Leadership in the Contemporary World'. Arent Lijphart (ed.) Parliamentary Versus Presidential Government. Oxford University Press.

Bobbio, Norberto (1989) Democracy and Dictatorship. Tr: Peter Kennealy. Oxford: Polity Press.

Eren-Vural, İpek (2007) "Siyasal İstikrarın Parlamenter Kökenleri: İngiltere Örneği Üzerine Bir Derleme". Kamalak, İbrahim der. Başkanlık Sistemi ve Türkiye. İstanbul: Kalkedon yayınları.

Eroğul, Cem (1997) Çağdaş Devlet Düzenleri. Ankara: İmaj Yayınları.

Gramsci; Antonio (2011) Hapishane Defterleri 1. Cilt. Joseph A. Buttigieg ed. Çev: Ekrem Ekici. İstanbul: Kalkedon Yayınları.

Iyigungor, Vildan (2002) "Küreselleşme ve Yürütmenin Güçlendirilmesi: Siyasal Sistem Tartışmaları". İstanbul Universitesi Siyasal Bilgiler Fakültesi Dergisi. Mart. sayı: 26: 85-103.

Jessop, Bob (2005) "Poulantzas'ın Özgünlüğü, Mirası ve Güncelliği". B. Yarar\&A. Özkazanç der. Hegemonya, Post-Fordizm ve Küreselleşme Ekseninde Kapitalist Devlet. İstanbul: İletişim Yayınları.

Kamalak, İbrahim der. (2007) Başkanlık Sistemi ve Türkiye. İstanbul: Kalkedon Yayınları.

Lijphart, Arend (1989) Çağdaş Demokrasiler. Çev: E. Özbudun \& E. Onulduran. Ankara: Türk Demokrasi Vakfı ve Siyasi İlimler Derneği. Lijphart, Arend ed. (1992) Parliamentary versus Presidential Government. Oxford: Oxford University Press.

Linz, Juan (1992)"The Perils of Presidentialism". Lijphart, A ed. Parliamentary versus Presidential Government. Oxford: Oxford University Press.

Linz, Juan (1994) "Presedential or Parliamentary Democracy". Linz, Juan \& Valenzuela, Arturo ed. The Failure of Presidential Democracy. John Hopkins University Press.

Marks, Karl (1976) Louis Bonaparte'ın 18 Brumaire'i. Çev: Sevim Belli. Ankara: Sol Yayınları.

Özdemir, Ali Murat \& Çelebi, Hüseyin (2007) "Başkanlık Sistemi, Birikim Stratejileri ve yeni Hukuk: Türkiye'de Hükümeti Biçimlendirmek". Kamalak, İbrahim der. Başkanlık Sistemi ve Türkiye. İstanbul: Kalkedon yayınları.

Poulantzas, Nicos (1980) Faşizm ve Diktatörlük. Çev: Ahmet İnsel. İstanbul: Birikim Yayınları.

Poulantzas, Nicos (2004) Devlet, İktidar, Sosyalizm. Çev: Turhan Ilgaz. Ankara: epos Yayınları.

Sartori, Giovanni (1994) "Neither Presidentialism nor Parliamentarism". Linz, Juan \& Valenzuela, Arturo ed. The Failure of Presidential Democracy. John Hopkins University Press.

Sartori, Giovanni (1997) Karşılaştırmalı Anayasa Mühendisliği. Çev: Ergun Özbudun. Ankara: Yetkin Yayınları.

Stepan, Alfred \& Skach, Cindy (1994) "Presidentialism and Parliamentarism". Linz, Juan \& Valenzuela, Arturo ed. The Failure of Presidential Democracy. John Hopkins University Press.

Yetiş, Mehmet (1996) İdeolojik Hegemonya Sorunsalı. Yayınlanmamış Doktora Tezi. Ankara: AÜ Sosyal Bilimler Enstitüsü. 